\title{
Enhancing reproductive performance in domestic dairy water buffalo (Bubalus bubalis)
}

\author{
L Zicarelli \\ Dipartimento di Scienze Zootecniche e Ispezione degli Alimenti - Università "Federico II" - \\ Napoli Via Delpino, 180137 Napoli, Italy
}

The purpose of the review is to describe the factors that affect fertility in domestic water buffalo (Bubalus bubalis) and the techniques that enable an improvement in reproductive performance. On Italian and Latin American farms where natural mating is practiced and bulls are always present in the herd, the inter-calving interval is approximately 400 days and the culling rate is lower than $15 \%$. The buffalo has a tendency for seasonal reproductive activity. Reproduction is favoured when there is a decrease in day length. Ovarian activity stops if conception does not occur within 3 to 5 ovarian cycles. It is important, therefore, that appropriate management of the transition period is practiced, particularly with respect to the hygienic conditions of the uterus. In tropical countries located north of the equator, feed deficiencies and heat stress are considered the main factors that lead to poor fertility in the summer. In Pakistan, for example, the increase in body condition score during the autumn was associated with the commencement of the breeding season in buffaloes. Anoestrus is observed also in Italy, however, where the average daily temperature during the same period is 13.5 to $23.5^{\circ} \mathrm{C}$ and feeding is constant throughout the year. The only common element between the two areas is the progressive increase in daylight hours between April and June and the day length greater than 12 hours up to September. In Italian herds that apply an out-of-season breeding strategy, an improvement in fertility (measured as the percentage of corpora lutea corresponding to subsequent pregnancy) is observed when water pools are present on the farm. This demonstrates that an improvement in environmental conditions reduces the incidence of embryonic mortality and/or abnormal cycles. To summarize, in the absence of serious nutritional problems, an improvement in environmental conditions increases fertility in buffalo.

\section{Introduction}

Domestic water buffalo (Bubalus bubalis) represent a fundamental and irreplaceable resource for tropical countries. Buffalo populations are increasing at a greater rate than those of bovine species. Between 1961 and 2008, the bovine and buffalo populations increased by $43 \%$ and $105 \%$ and between 1995 and 2007 increased by $2 \%$ and 13\%, respectively (Faostat.fao.org/) faostat). The population data refer to the population present in 43 of 143 countries that currently breed buffalo (Misra \& Tyagi 2007). 
The majority of the authors believe that the main reproductive characteristics of buffalo are delayed puberty, prolonged postpartum ovarian inactivity, long inter-calving intervals and a tendency for seasonality (Madan 1988; Misra \& Tyagi 2007). The reproductive problems depend on the region of the world. In tropical countries north of the equator (TCNE), for example, the majority of the authors assert that the summer anoestrus is caused by heat stress and forage scarcity. In Italy, however, anoestrus is observed in the same period of the year as TCNE (as demonstrated by the calving distribution; Fig. 1) although the diet in Italy is constant throughout the year and the ambient temperatures are milder. The aim of this review is to examine the main factors affecting fertility in buffalo and the strategies that may be adopted to enhance the reproductive performance of buffalo.

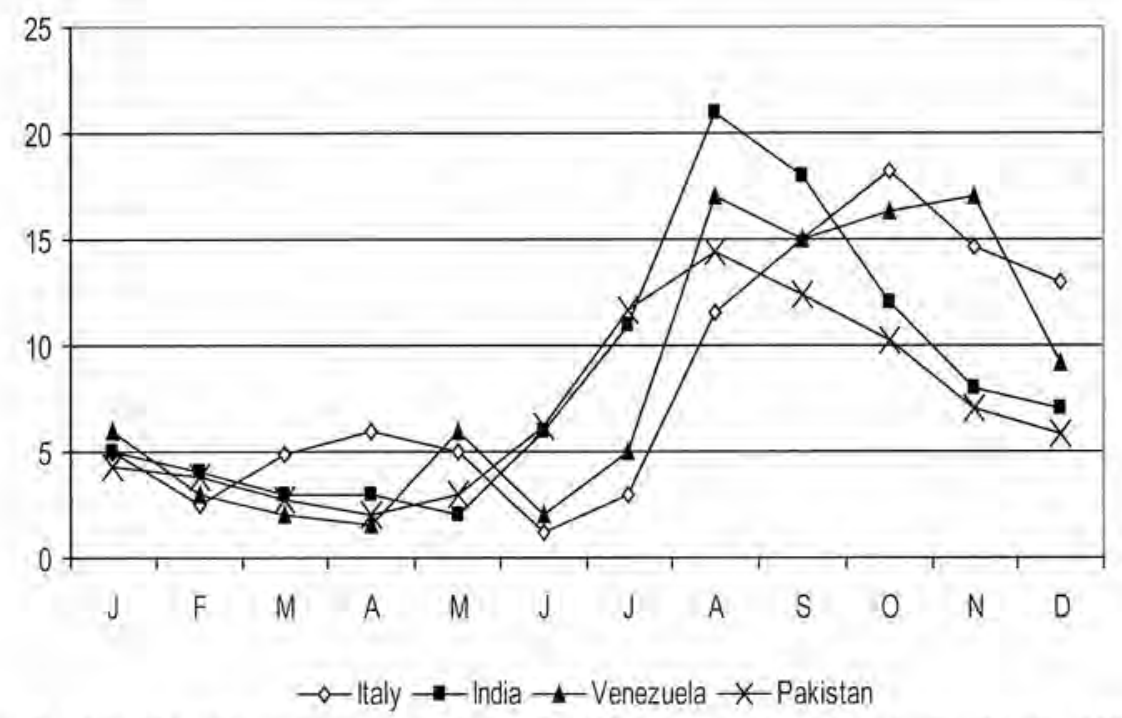

Fig. 1. Monthly calving percentage for Italy (Zicarelli et al. 1977), India (Singh, 1988), Venezuela (Zicarelli, 1994), and Pakistan (Hassan et al. 2007). Calendar months (single letter abbreviations) are indicated on the x-axis.

\section{Reproductive seasonality}

The place of origin and the duration of gestation have undoubtedly influenced the way in which reproductive seasonality occurs. The natural necessity to coincide calving and weaning with the most-suitable time of year represents one of the causes of this 'adaptation' process (Zicarelli 1994). This time of year should satisfy the nutritional requirements of the offspring through a period in which etiologic agents (infectious and parasites) are less aggressive and/ or present. Those born under the most-favourable conditions have brought about the natural selection of individuals endowed with a more ideal reproductive seasonality that promotes the survival of the species (Zicarelli 1997). Spring calving (March to May), which guarantees good availability of forage to offspring in temperate zones north of the equator, occurs when reproduction takes place in autumn in the case of five month gestations (sheep and goats) or in the previous spring in the case of 11 and 12 month gestations (horses and donkeys). The same calving period, therefore, is conditioned by the neuroendocrine system. The reactivation of the reproductive cycle with regard to the length of gestation (short day breeder [negative photoperiod] or long breeder [positive photoperiod]) is therefore controlled. 
In tropical zones where the domestic buffalo developed (between $31^{\circ} \mathrm{N}$ and $2^{\circ} \mathrm{S}$ ) forage availability is usually adequate after the rainy season (July through September). In species like the domestic buffalo, therefore, whose pregnancy lasts 310 to 316 days, the sensitivity to decreasing light stimulus and the reproductive season seems to take place between September and January. Around the equatorial belt, where the light/dark ratio varies little throughout the year, the reproductive season is highly conditioned by forage availability (Vale et al. 1990; 1996). There is a tendency towards seasonality in buffalo because buffalo evolved far away from the equator. Moving buffalo to other regions of the world has not modified the sensitivity of the hypothalamic hypophyseal axis to a decreasing light/dark ratio.

In Italy, the seasonality makes it necessary to change the calving calendar in order to meet the milk market demand. This is accomplished by using an out-of-breeding mating strategy (OBMS) that entails the interruption of natural mating or the use of artificial insemination (Al) between October and late January in adult females and between September and late March in heifers. These months are the most-favourable periods for reproductive activity (Zicarelli 1994; Zicarelli 1997; Campanile et al. 2009).

In research carried out in Italy (Parmeggiani \& Di Palo 1994), it was demonstrated that buffaloes with a tendency towards seasonality showed high plasma melatonin concentrations two hours after sunset even when they were moved to another farm where other females showed low plasma melatonin concentrations and less sensitivity towards light stimulation (Di Palo et al. 1997). The plasma melatonin concentrations had a repeatability of 0.733 (Di Palo et al. 1993). If the heredity of plasma melatonin turns out to be high, as we expect based on the high repeatability, the plasma melatonin could be incorporated into genetic selection programmes for buffalo (Zicarelli 1994). In an effort to validate this theory, we reported that Romanov $58^{\circ} \mathrm{N}$, Karakul $41^{\circ} \mathrm{N}$ and White-faced $51^{\circ} \mathrm{N}$ sheep (Lincoln 1992) showed continuous cyclic activity throughout the year even if living at latitudes where other genotypes were sensitive to the light/dark ratio.

In heifers and adult female buffaloes, the differences between night and day concentrations of plasma melatonin in March were less in heifers (5.0 times) compared with adult buffaloes (28.3 times) (Borghese et al. 1995). Both buffaloes that calve in spring (Di Palo et al. 1993; more adaptable to out-of-breeding-mating-strategy) and the heifers (Borghese et al. 1995; less sensitive to the photoperiod; Zicarelli 1994) show the same behavioural pattern.

Heifer fertility is not compromised by the season (Campanile et al. 1991; Avallone et al. 1994; Zicarelli 1994). During the summer and when daylight hours are more than dark hours, there is an increase in prolactin in the blood but, contrary to assertions by Madan (1988), buffalo regularly conceive. We believe that hyperprolactinemia is a consequence of the hypothyroidism (Campanile et al. 1994) during the warm months. The hypothyroidism exerts a positive feedback on thyroid stimulating hormone and hence on thyrotropin releasing hormone. Thyrotropin releasing hormone promotes an increase in prolactin (Zicarelli 1994; 1997).

The majority of authors attribute reproductive seasonality to nutritional factors. The breeding period in areas where $97 \%$ of the buffalo population are bred takes place in the months of greater forage availability (Roy et al. 1968; Singh et al. 1988; Shah 1990; Singh \& Lal 1992; Qureshi et al. 1999a). Greater forage availability is found during the months of July through November characterized by decreasing daylight length in TCNE.

Recently Hassan et al. (2007) reported the different seasonality of Nili-Ravi buffaloes, purebred Sahiwal and cross-bred cattle in Pakistan. The difference between Nili-Ravi buffaloes and purebred Sahiwal was characterized by negative and positive photoperiod sensitivity, respectively. Data similar to those recorded in buffaloes have been observed in cross-bred cattle (Holstein or Jersey $x$ Sahiwal). It cannot be ruled out, however, that the high temperatures $\left(35\right.$ to $41{ }^{\circ} \mathrm{C}$ ) and milder temperatures $\left(22\right.$ to $28^{\circ} \mathrm{C}$ ) may influence negatively and positively (respectively) 
the ovarian activity. This finding suggests, moreover, that crossbreeding with Bos taurus may modify the seasonality of native bovines, which have the higher incidence of deliveries during the first 5 months of the year and, hence, conceive in the hottest months (April to August).

If heat stress is the main cause of the anoestrus then it should adversely affect the reproductive activity of buffalo compared with Bos indicus cattle. In Italy exactly the opposite pattern is observed. For out-of-season mated buffaloes, the conception rate increases between July and September, a period during which Holstein cows shows a low conception rate.

In Italian herds where the OBMS technique is not used (Zicarelli et al. 1977) as well as 30 to 40 years ago on the majority of farms (Ferrara 1957), the resumption of the reproductive cycle (RRC) took place from September (decreasing light period) until January (light increasing period but predominantly dark hours) (Fig. 1). Sensitivity to the negative photoperiod is also found on farms where a constant balanced diet is provided year-round (Zicarelli 1994). This type of seasonality, where reproductive events are not synchronised with forage availability, indicates that the buffalo bred in Italy are not autochthonous in the sense that they will sometimes calve during periods of forage scarceness and low temperature which in turn hinders the survival of the calf. Italian findings should be sufficient to define the buffalo as a short day breeder. Indeed, a similar seasonality to that found in Italy and Asian tropical areas is also found in Venezuela (Montiel 2000) and Egypt (Zoheir et al. 2007) (Fig. 1).

In southern Brazil (Da Silva \& Grodzki 1991; Baruselli et al. 2001) and Argentina (L Zicarelli, unpublished observations), the wet season (and consequently, increased pasture availability) starts in October to November and continues until March to April. Pasture scarcity goes from May to June until October to November. The buffalo calving period under these conditions is mainly concentrated from February to May (Fig. 2). The breeding period is from April to July and the calf weaning calf period under free range and suckling calf conditions is from September to December. These events permit the coincidence of forage availability within the first 2 to 4 months of lactation and most of the dry period (October to April). The breeding period, however, is mainly concentrated during the pasture scarcity period (May to July).

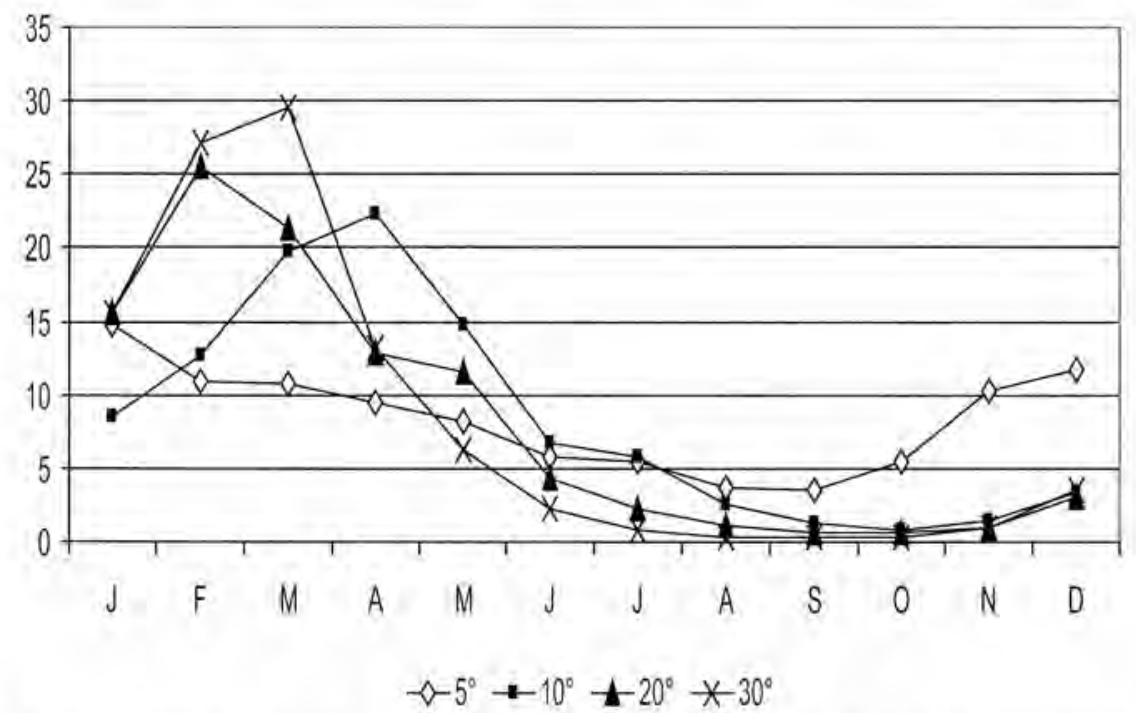

Fig. 2. Monthly calving percentage in Brazil as a function of latitude ( $\left.{ }^{\circ} \mathrm{S}\right)$. Calendar months (single letter abbreviations) are indicated on the $x$-axis. 
Baruselli et al. (2001), who evaluated data from the Brazilian Breeders Association, observed that the seasonality is more accentuated from the north (0 to 8 degrees latitude) to the south ( 24 to 32 degrees latitude) of Brazil (Fig. 2) and hence the calving season is influenced by latitude. From the findings shown here, it can be unequivocally stated that, although the domestic water buffalo shows reproductive activity throughout the year, there is a greater tendency to concentrate reproductive activity in months of decreasing daylight or if increasing, when dark hours prevail.

\section{Reproductive efficiency}

Many scientists affirm that the buffalo shows delayed puberty and a long inter-calving interval. These characteristics are affected by several factors, such as year of calving, season of delivery, genotype and heat stress (Zicarelli et al. 2007). The delayed puberty and the consequent older age at first calving have been addressed by many authors. In a study performed on 86 farms $(30,735$ primiparous buffaloes, which calved between 1975 and 2005$)$, it was observed that the mean age at first calving decreased by 1 month every 5 years (Zicarelli 2007). The hormonal pattern in cyclic buffalo is similar to that described in a cyclic Bos taurus cow (Seren et al. 1994). The main difference between the two species is the percentage of cyclic individuals in the different seasons.

The different reproductive efficiency of buffalo compared with Bos taurus is due to several features. These features must be considered because there is a need to modify the calving calendar in the buffalo so that the milk market demand is met. There are fewer primordial and antral follicles (Le Van et al. 1989) as well as a lesser ovarian weight and lesser ovarian volume in the buffalo compared with the bovine (Vittoria 1997). The number of oocytes in a buffalo calf is one-fifth that recorded in a bovine calf (Le Van et al. 1989; Gasparrini 2002). After calving, there are a low number of ovarian follicles and follicular waves and few cycles occur. If conception does not take place, therefore, an anoestrus of variable length begins (Zicarelli et al. 1994). With regard to this topic, the transition period and the postpartum period have a major importance for fertility in buffalo. It should be pointed out that in the farms adopting semi-free housing, the presence of mycotoxins in the roughages, Clostridia, Coxiella burnetii, and the incorrect input of $\mathrm{Ca}, \mathrm{P}$ and crude protein in the last two months of pregnancy often lead to the occurrence of vaginal or uterine prolapse which impairs the RRC (Zicarelli 2000). It is not clear whether the seasonality of the species depends on the reduced follicular population or if this latter effect is the cause of buffalo seasonality.

If the calving calendar is not modified, the delayed RRC after calving can be due to the lack of the "bull effect" (Zicarelli et al. 1997) and/or to poor nutritional conditions. In small farms in TCNE where the bull is not present, the dry period of the animals (March to June) coincides with the scarcity of forage. South of the equator over the 20th parallel, the dry period (November to March) coincides with the abundance of forage and the bull is always present in the herd. In the first case, prolonged inter-calving intervals are observed (Shah 1990) whereas in the second case inter-calving intervals less than 400 days are recorded (Zicarelli 1994).

These observations suggest that in those areas, the meeeting of nutritional requirements and the absence/presence of the bull are the most important factors (Zicarelli et al. 1997), especially taking into account that the protein content of the pastures is very low (6 to $10 \%$ of DM) and leguminosae are found in irrigated areas or during the rainy season. In Pakistan, Qureshi et al. (1999a, 1999b) reported that the seasonality is influenced by nutritional and non-nutritional factors. Unless the feed deficiencies are serious, however, nutritional factors in general do not play a significant role (Zicarelli 1999; Paul \& Lal 2010). The buffalo cannot yet be considered 
exactly as having a "lactiferous habitus" and therefore a "catabolicus habitus" such as that found in the high milk producing bovine cow which uses its reserves to compensate energy and protein deficiency during early lactation. As a matter of fact, within reasonable limits, the buffalo uses its reserves in its aim to reproduce and to the detriment of her own milk production.

The effects of the tendency toward seasonal reproduction in the buffalo are particularly evident. Studies conducted in Italy may be useful for countries wishing to increase the consistency of their production of buffalo milk during the year. When primiparous buffaloes are excluded from the survey (heifers are less sensitive to photoperiod), a decrease in calving rate between March and June for farms that are adopting the OBMS technique is observed in Italy whether OBMS is applied or not (Fig. 3). This confirms that the increase in daylight hours (April to June) or number of daylight hours $>12 \mathrm{~h}$, negatively interfere with reproductive activity. The buffalo that undergo OBMS can show anoestrus and this phenomenon is worsened by unfavourable climatic conditions.

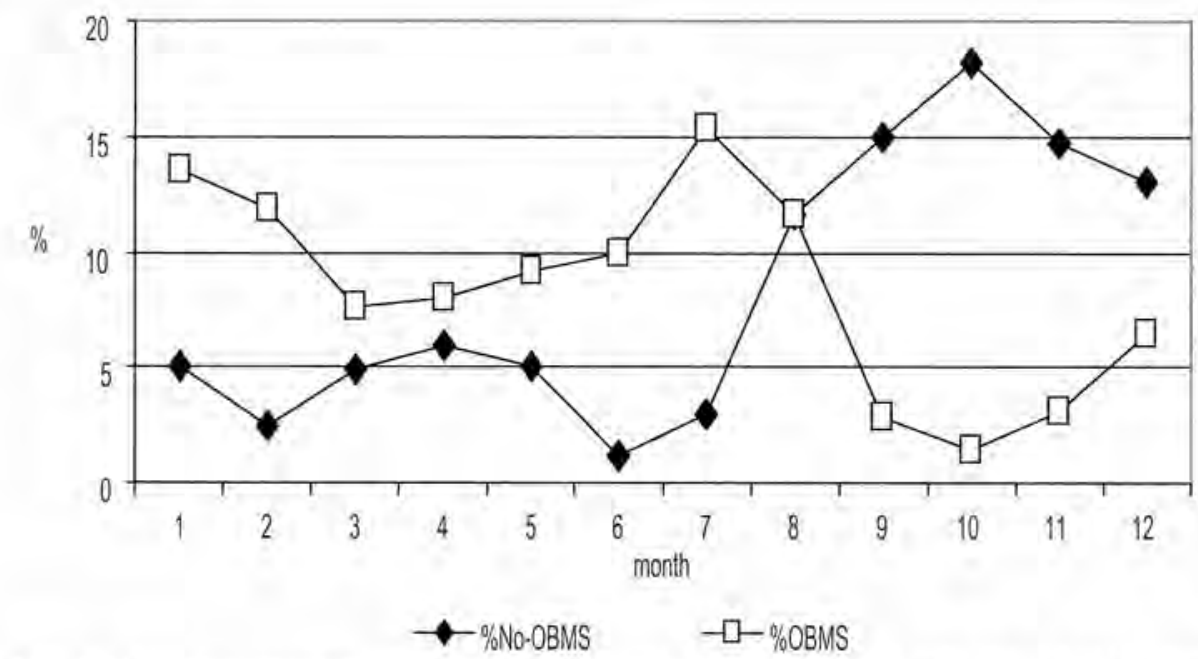

Fig. 3. Calving percentage in farms that use ( $\%$ OBMS) or do not use ( $\%$ No-OBMS) the out-of-breeding mating strategy (OBMS) technique.

It is possible to define a "temporary anoestrus" ( $<150$ days) and a "deep anoestrus" ( $>150$ days) based on the number of days open. It is also possible to distinguish between buffalo that come into oestrus within 70 days from calving, and conceive within or after 90 days, from those that come into oestrus after 70 days and conceive within or after 150 days (Zicarelli et al. 1994). Approximately $70 \%$ of buffaloes that deliver out of the breeding season showed RRC within 70 days from calving. Fifty-three percent of these buffalo were able to conceive within 3 months (around $75 \%$ of the animals that resumed the ovarian activity within 70 days) whereas $17.3 \%$ later than 3 months. The remaining $30 \%$ of animals had RRC after 70 days from calving and $10.6 \%$ and $18.8 \%$ conceived within and after 5 months, respectively.

Anoestrus can be identified as a non RRC after parturition or as an interruption of cyclic activity for varying reasons. Environmental conditions that are responsible for the anoestrus are accompanied by changes in blood hormones (Jain 1988) such as prolactin (Razdan et al. 1981), follicle stimulating hormone (Janakiraman et al. 1980), luteinizing hormone (Batra \& Pandey 1982; Aboul-Ela et al. 1983), progesterone (Kaur et al. 1983; Qureshi et al. 2000), estradiol (Sheth et al. 1978; Heranjal et al. 1979; Razdan et al. 1981), thyroid hormones (Khurana \& Madan 1985; Gupta \& Dhoble 1988), and corticosteroids (Madan et al. 1983). 
Some of these hormones represent the response to stressful factors rather than the cause of the arrest in reproductive activity. Buffalo that deliver out of the breeding season may need several months to conceive. During this period, they are not always acyclic, but are able to conceive and then undergo embryonic mortality, in particular between April and May, months characterized by progressively increasing day length. During the year, the embryonic mortality rate is $10 \%$ of the pregnancies diagnosed at 40 days and is $22 \%$ for pregnancies that take place in the month of April (Zicarelli et al. 1994). The incidence of this event is affected by the "farm" factor and ranges between 10 and $45 \%$ if calculated on the pregnancies after Al diagnosed by ultrasonography at day 26 (Campanile et al. 2005).

A pregnancy is not always detected after the observation of a corpus luteum. It can be assumed that an early embryonic mortality or an anoestrus condition has occurred. The anoestrus condition may have been preceded by an ovarian cycle which forms a corpus luteum with inadequate function because of a short luteal phase or normal luteal phase with low progesterone (Zicarelli 1997; Zicarelli et al. 1997). This phenomenon has been found at the onset of anoestrus season in sheep, after first ovulation postpartum in bovine and during the prepubertal phase in both species (Garverick et al. 1992).

Some recent papers report an incidence of double ovulations of $15.5 \%$ in dairy cows (LopezGautius et al. 2005). A similar value has been previously reported in buffalo (Zicarelli et al. 1988). In the latter, however, only $0.06 \%$ of double ovulation led to a twin pregnancy. The double ovulations reduce the efficiency of $\mathrm{Al}$ in the case of spontaneous oestruses, but not in the case of induced oestruses (Zicarelli et al. 1997).

In Italy, the OBMS technique leads to lesser fertility. In fact, when the OBMS technique was not applied, calving intervals of 400 to 445 days were recorded (Zicarelli et al. 2007). Recently, a mean inter-calving interval of $487 \pm 133$ days was reported for 6,052 inter-calving intervals over a period of 5 to 10 years on 5 farms with an annual culling rate lower than $10 \%$ (Zicarelli et al. 2007). The OBMS technique was adopted and constant rationing was given throughout the year. It was demonstrated that the shortest inter-calving periods were recorded in buffaloes that deliver between April and June, and that, consequently, conceived in the warmest months. (between June and August). Short inter-calving intervals were also found in buffalo that delivered between July and September; the period of the year during which the highest temperatures are recorded in Italy. The longest inter-calving periods were recorded for buffaloes calving between October and December, because of the OBMS technique, which delays mating until February. Long inter-calving intervals were also found in buffaloes that calved between January and March, the coldest period of the year (Zicarelli et al. 1994; 1997; 2007). These buffalo would conceive in spring, the mildest period of the year, characterized by temperatures between 15 and $22^{\circ} \mathrm{C}$. Conception is typically delayed until September, however, except for the $40 \%$ of animals that conceive within 90 days from calving. We can conclude, therefore, that in Italy nutrition and the warmest months, especially if a swimming-pool is present on the farm (Di Palo et al. 2009; Neglia et al. 2009), do not affect the inter-calving period. The main factor that has to be taken into account in Italy is the light stimulus. Buffaloes that deliver between January and March delay their conception until August to September, after three months of decreasing day length. Similarly, buffaloes that deliver in the period April to September show the shortest inter-calving period because after 58 days decreasing day length begins.

The majority of Indian and Egyptian authors assert that the lower concentration of calving observed between January and May depends on the reduced conception rate between March and July. This phenomenon is influenced by the hot and dry climate of this period of the year. In Italy, in farms that do not use the OBMS, a drop of calving is also observed between January and June (Fig. 1); a period of the year in which, unlike India, the climate is either cold or mild and moderately rainy. The fertility markedly improves between July and September; a period 
that in Italy coincides with the highest temperature (Fig. 4) and temperature humidity index of the year. This observation makes buffalo very different from cattle, that in the hottest months of the year (July to September), show a marked decrease in fertility.

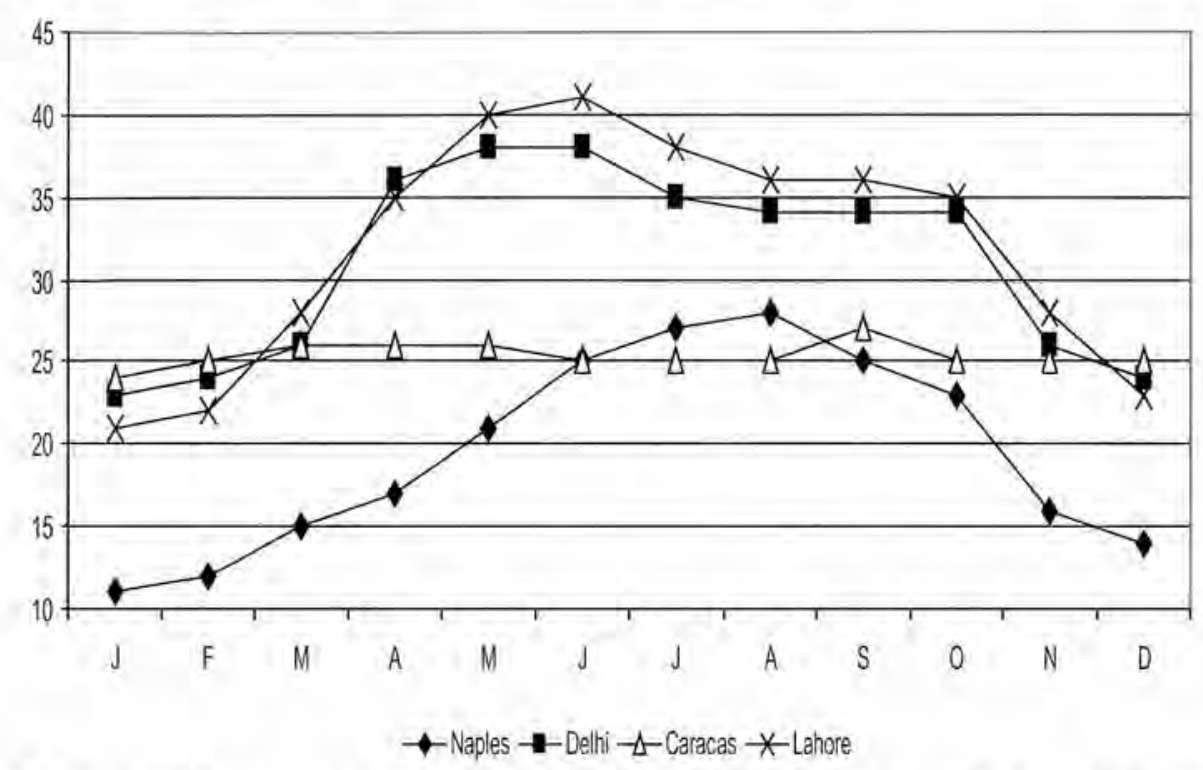

Fig. 4. Monthly maximum temperature $\left({ }^{\circ} \mathrm{C}\right)$ in Naples, Delhi, Caracas, and Lahore. Calendar months (single letter abbreviations) are indicated on the x-axis.

We have already highlighted that in the areas located north of the equator a drop in the number of calvings is observed between January and June. The authors from countries located north of the equator attribute the anoestrus of buffalo to heat stress (India, Pakistan) or to the low environmental humidity (Venezuela). In our opinion, the decrease in calving rate between January and June (Fig. 1) depends on the reduced reproductive activity between March and September. In the latter period, the maximum daily temperature (Fig. 4) ranges between $15^{\circ} \mathrm{C}$ (March) and $27^{\circ} \mathrm{C}$ (August) in Naples, Italy; between $25^{\circ} \mathrm{C}$ and $38^{\circ} \mathrm{C}$ in Delhi, India; between $27^{\circ} \mathrm{C}$ (March) and $41^{\circ} \mathrm{C}$ (June) in Lahore, Pakistan; and between $25^{\circ} \mathrm{C}$ (March) and $26^{\circ} \mathrm{C}$ (August) in Caracas, Venezuela. The maximum daily temperatures that are recorded in Italy and in Venezuela rule out a direct action of environmental temperature on anoestrus. If only India and Pakistan are considered, it is not possible to exclude that heat stress, even if it is not the main factor, contributes to summer anoestrus. Furthermore, the RRC (August to September) coincides with a monthly maximum temperature of $28^{\circ} \mathrm{C}$ (August) and $25^{\circ} \mathrm{C}$ (September) in Italy, $25^{\circ} \mathrm{C}$ (August) and $27^{\circ} \mathrm{C}$ (September) in Venezuela, $34^{\circ} \mathrm{C}$ (September) in India and $36^{\circ} \mathrm{C}$ in Pakistan.

The monthly rainfall recorded in Italy and Venezuela between September and October is not different from that observed between March and May (Italy) and between June and August (Venezuela) when the lower conception rate is observed (Fig. 5). On the contrary, in India and in Pakistan the rainy season takes place between July and September. The cessation of reproductive activity in Italy and Venezuela, therefore, cannot be attributed to the rainfall. In India and Pakistan, the reproductive activity is good in October and November (calving August and September), when the temperature is lower and the rainfall is already minimal. The trend of daylight hours, although with different daily values, is shared by all the areas of breeding situated north of the equator (Fig. 6). Interestingly, a 4-year retrospective analysis of data (B Gasparrini, 


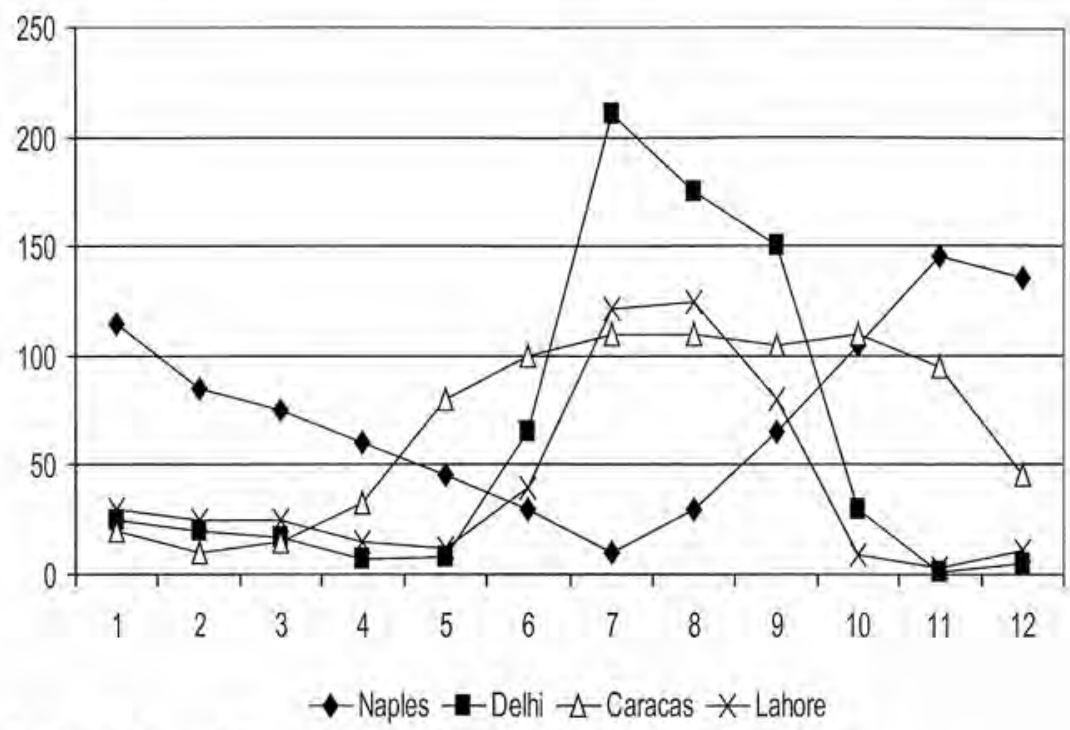

Fig. 5. Monthly rainfall ( $\mathrm{mm})$ in Naples, Delhi, Caracas, and Lahore.

unpublished observations) obtained in an in vitro embryo production laboratory showed that a significant decrease in blastocyst rate was observed between April to June compared with October to December. Intermediate values were recorded between July and September and between January and March. The drop in oocyte developmental competence coincides with the spring months that at our latitudes are characterized by mild environmental temperatures. This pattern confirms that the light stimulus plays the most critical role in determining seasonality.

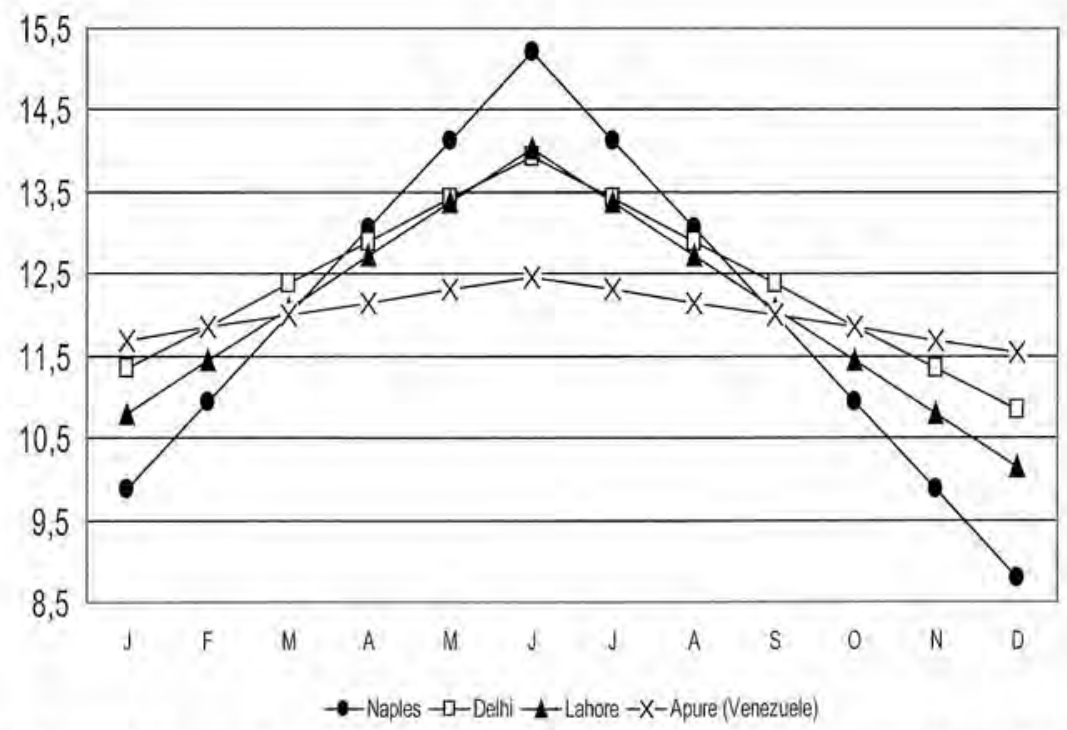

Fig. 6. Daylight hours (h) in Naples, Delhi, Appure (Venezuela), and Lahore. Calendar months (single letter abbreviations) are indicated on the $\mathrm{x}$-axis.

South of the equator, Baruselli et al. (2001) demonstrated that the concentration of calving increases proportionally with increasing distance from the equator (Fig. 2). It is not possible to 
show any relationship between daily maximum temperature, rainfall and the calving calendar (Fig. 2) whereas an evident relationship exists between the calving calendar and the daylight hours at different latitudes (Fig. 7).

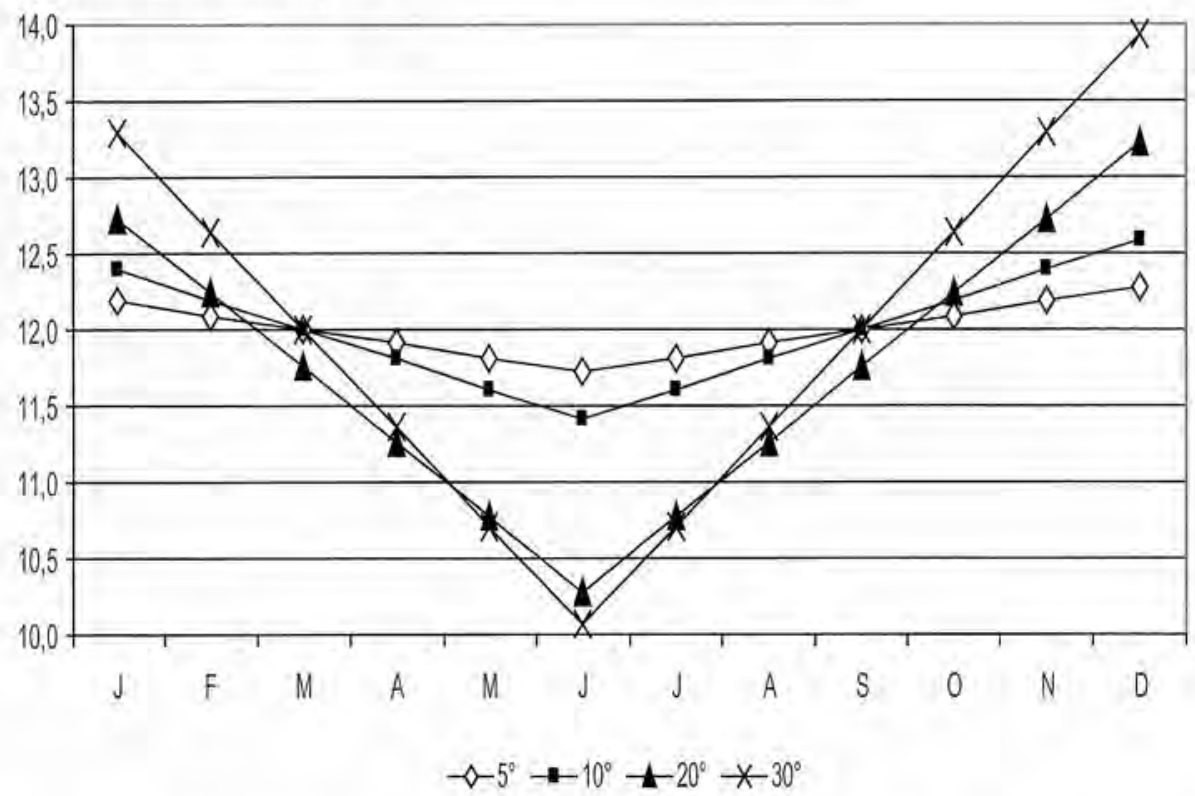

Fig. 7. Daylight hours (h) in Brazil as a function of latitude $\left({ }^{\circ} \mathrm{S}\right)$. Calendar months (single letter abbreviations) are indicated on the $x$-axis.

Throughout this paper, the seasonality of the females has been considered. The phenomenon may affect the males as well. The effects are clear when the animals are maintained in free mounting condition. Recently, we observed in the same farm a higher pregnancy rate between January and April in buffaloes inseminated by Al compared with buffalo that were bred by using the bull. This perhaps occurred because the Al avoided the negative effect of the bull. We have recently verified that in April, only $23 \%, 31 \%$ and $29 \%$ of the bulls showed values higher than the average value for testosterone, diihydrotestosterone and androstenedione, respectively (Pelagalli et al. 2009).

\section{Strategies to enhance reproductive performance}

The delayed puberty and the consequent older age at first calving depend on both inappropriate weaning techniques and inadequate feeding during growth. The age at first calving was 28 to 32 months when feeding a diet characterized by an energy density of 0.8 MUF (MUF = Milk unit forages $=1700 \mathrm{kcal} \mathrm{NE}$ ) and 12.5 to $13 \%$ protein content on a dry matter basis and a forage to concentrate ratio of 50 to $60 \%$, (Zicarelli 2007). Embryonic mortality in buffalo is primarily due to a reduced secretion of progesterone by the corpus luteum. The importance of progesterone concentration during the first weeks of pregnancy for reducing embryonic mortality has been demonstrated in both cattle (Mann 2002) and buffalo (Campanile et al. $2005 ; 2007 ; 2008 ; 2009)$. In cattle, several treatments have been used typically within 5 days after conception to increase progesterone secretion by the existing corpus luteum or to induce ovulation and formation of an accessory corpus luteum (Mann 2002). Treatments on day 5 after 
insemination do not have any effect on reducing embryonic mortality in buffalo (Campanile et al. 2007). Treatment of buffaloes with a GnRH agonist, hCG or progesterone on day 25 after Al reduced embryonic mortality (Campanile et al. 2008).

Although the light/dark ratio is the main factor affecting reproductive efficiency, another important factor is the satisfaction of the buffalo's physiological need of water for bathing. The presence of a swimming-pool reduced the not pregnant buffaloes per corpora lutea ratio (NP/ $\mathrm{CL}$ ) found at rectal examination in buffaloes that calved between April and August (Di Palo et al. 2009; Neglia et al. 2009). The swimming pool apparently acted to reduce heat stress. The NP/CL ratio, as an indicator of an anomalous oestrous cycle or embryonic mortality, may be proposed as a specific tool for evaluating buffalo welfare (Di Palo et al. 2009).

The treatments for anoestrus are based on the use of progesterone devices combined with PMSG. The response is influenced by the effects of year and farm and are, therefore, variable. The above treatments in natural mating conditions do not have an immediate impact but in primiparous females they have a beneficial effect on the RRC. Unsatisfactory responses are perhaps more useful because they lead to the assessment of the environmental causes that underlie the reproductive failures (Zicarelli et al. 1994). For instance, we demonstrated that more space and better welfare conditions improved fertility in Italy. On 21 farms in which the OBMS is performed we observed that $38.1 \%, 52.4 \%$ and $4.8 \%$ of the farms increased fertility rate respectively in June, July to August and September (L. Zicarelli, unpublished observations). Out of the 8 farms that resumed fertility in June, $6(75 \%)$ had at their disposal either covered sheds, that shorten the day length on average by $2 \mathrm{~h}$ during the year, or wide open spaces in which buffalo cows can move for at least $6 \mathrm{~h} /$ day or swimming pools. Out of the 11 farms that resumed fertility in July only $2(18.2 \%)$ had swimming pools available $(6 / 8$ versus $2 / 11)$. In a farm with a variable number of breedings over 10 years, an increase in reproductive activity in June and July was recorded. Between January and June $77 \%$ and $68 \%$ of calving were observed, respectively, for 352 and 451 buffaloes. These finding suggest that the effects of season can in part be attenuated by improving the welfare status of the animals.

\section{Conclusions}

The seasonality in buffalo is influenced by the light/dark ratio throughout the year. In some countries the seasonality is influenced by nutritional factors. Furthermore, an improvement in the welfare of buffalo (swimming pool, space, brightness of the stalls, etc.) can increase the percentage of calvings between March and June. Delayed treatment of buffaloes with GnRH agonist, hCG or progesterone on day 25 after $\mathrm{Al}$ can reduce embryonic mortality in the months in which daylight hours increase. A significant improvement in reproductive efficiency can be achieved by increasing the culling rate from $10-14 \%$ to $25-30 \%$, and hence eliminating older buffalo and those with reproductive problems.

\section{References}

Aboul-Ela MB, El-Keraby FE \& Chesworth JM 1983 Seasonal variation in the $\mathrm{LH}$ release in response to GnRH in the buffalo. Anim. Reprod. Sci. 6229-232.

Avallone L, Parmeggiani A, Esposito L \& Campanile G 1994 Correlation between prolactin, T3 and T4 levels in buffalo heifers during the whole year. Proceedings of the Fourth World Buffalo Congress, Săo Paulo, p. $477-479$.
Baruselli PS, Bernardes O, Braga DPAF, Araujo DC \& Tonhati H 2001 Calving distribution throughout the year in buffalo raised all over Brazil. Proceedings of the Sixth World Buffalo Congress, Maracaibo, Venezuela, p. 234-239.

Batra SK \& Pandey RS 1982 Luteinizing hormone and oestradiol-17B in blood plasma and milk during the estrous cycle and early pregnancy in Murrah buffaloes. 
Anim. Reprod. Sci. 5 247-257.

Borghese A, Barile VL, Terzano GM, Pilla AM \& Parmeggiani A 1995 Melatonin trend during season in heifers and buffalo cow. Bubalus bubalis 1 61-64.

Campanile G, Shehu D, Esposito L, Di Palo R, Montemurro N, Zicarelli L, Terzano GM \& Borghese A 1991 Onset of ovarian activity in Italian buffalo heifers. Proceedings of the Third World Buffalo Congress, Varna, p. 666-671.

Campanile G, Avallone L, d'Angelo A, Di Palo R \& Di Meo C 1994 Influence of the season and of the number of days after calving on the pattern of thyroid hormones in buffalo cows. Proceedings of the Fourth World Buffalo Congress, Săo Paulo, p. 564-566.

Campanile G, Neglia G, Gasparrini B, Galiero G, Prandi A, Di Palo R, D'Occhio MJ \& Zicarelli L 2005 Embryonic mortality in buffaloes synchronized and mated by $\mathrm{Al}$ during the seasonal decline in reproductive function. Theriogenology 63 2334-2340.

Campanile G, Di Palo R, Neglia G, Vecchio D, Gasparrini B, Prandi A, Galiero G \& D'Occhio MJ 2007 Corpus luteum function and embryonic mortality in buffaloes treated with a GnRH agonist, hCG and progesterone. Theriogenology 67 1393-1398.

Campanile G, Vecchio D, Di Palo R, Neglia G, Gasparrini B, Prandi A, Zicarelli L \& D'Occhio MJ 2008 Delayed treatment with $\mathrm{GnRH}$ agonist, hCG and progesterone and reduced embryonic mortality in buffaloes. Theriogenology 70 1544-1549.

Campanile G, Neglia G, Vecchio D, Russo M \& Zicarelli L 2009 Pregnancy in buffalo cows. In: Pregnancy Protein Research, p. 31-91, M. O'Leary and J. Arnett (Eds), Nova Science Publishers, Inc., New York.

Da Silva MET \& Grodzki L 1991 Study of correlations between climatic factors and seasonal fertility of female buffaloes in the Northeast of the state of Parana. Brazil. Proceedings of the Third World Buffalo Congress, Varna, p. 689-700.

Di Palo R, Parmeggiani A, Campanile G \& Zicarelli L 1993 Repeatability of melatonin plasma levels in buffaloes bred in Italy. Atti della Societa Italiana delle Scienze Veterinarie, 47 331-335.

Di Palo R, Parmeggiani A, Spadetta M, Campanile G, Esposito L, Seren E \& Zicarelli L 1997 Influence of changing farm on the repeatability of melatonin plasma level in Italian Mediterranean buffalo. Proceedings of the Fifth World Buffalo Congress, Caserta, p. 758-761.

Di Palo R, Ariota B, Zicarelli F, De Blasi M, Zicarelli G \& Gasparrini B 2009 Incidence of pregnancy failures in buffaloes with different rearing system. Ital. I. Anim. Sci. 8 (Suppl. 2) 619-621.

Ferrara B 1957. Ricerche su alcune statistiche vitali nella popolazione bufalina dell'Italia Meridionale. Nota II: intervallo interparto e distribuzione dei parti. Acta Med. Vet. 3 225-233.

Garverick HA, Zollers VG \& Smith MF 1992 Mechanisms associated with corpus luteum lifespan in animals having normal or subnormal luteal function. Anim. Reprod. Sci. $28111-124$.

Gasparrini B 2002 In vitro embryo production in buffalo species: state of the art. Theriogenology $57237-256$. Gupta SK \& Dhoble RL. 1988 Response of suboestrus rural buffaloes to PGF $2 \alpha$ analogue in relation to levels of triiodothyronine (T3), tetraiodothyronine/ thyroxine (T4) and progesterone. Proceedings of the Second World Buffalo Congress, New Delhi, India.

Hassan F, Khan MS, Rehman MS, Sarwar M \& Bhatti SA 2007 Seasonality of calving in Nili-Ravi Buffaloes, purebred Sahiwal and cross-bred cattle in Pakistan. Ital. I. Anim. Sci. 6 (Suppl. 2) 1298-1301.

Heranjal DD, Sheth AR, Wadadekar KB, Desai R \& Rao SS 1979 Serum gonadotrophins and prolactin in anoestrus buffaloes. Indian 1. Dairy Sci. 32 383-385.

Jain GC 1988 Hormonal profiles in anoestrus rural buffaloes. Proceeding of the SecondWorld Buffalo Congress, New Delhi, India, p. 39.

Janakiraman K, Desai MC, Anim DR, Sheth AR, Moodbird SB \& Wadadekar KB 1980 Serum gonadotropin levels in buffaloes in relation to phases of oestrous cycle and breeding periods, Indian I. Anim. Sci. 50 601-606.

Kaur H, Arora SP \& Sawhney A 1983 Progesterone and estradiol $-17 ß$ concentrations in blood plasma of buffaloes during different reproductive disorders. Indian 1. Anim. Reprod, 362 .

Khurana ML \& Madan ML 1985 Thyroxin secretion rate in buffaloes during hot dry, hot humid and cold season. Proceedings of the First World Buffalo Congress, Cairo, Egypt, p. 1165.

Le Van TY, Chupin D \& Driancurt MA 1989 Ovarian follicular populations in buffaloes and cows. Anim. Reprod. Sci. 19 171-178.

Lincoln GA 1992 Photoperiod-pineal-hypothalamic relay in sheep. Anim. Reprod. Sci. 28 203-217.

Lopez-Gautius F, Lopez Bejar M, Fenech M \& Hunter RH 2005 Ovulation failure and double ovulation in dairy cattle; risk factors and effects. Theriogenology 63 1298-1307.

Madan ML 1988 Status of reproduction in female buffalo. Proceedings of the Second World Buffalo Congress, New Delhi, p. 89-100.

Madan ML, Naqvi SMK, Triu CV, Suri AK \& Prakash BS 1983 Plasma estradiol - 17ß, progesterone and cortisol among anestrus rural animals. Indian J. Anim. Reprod. 360

Mann GE 2002 Corpus luteum function and early embryonic death in the bovine. Proceedings of XXII World Buiatrics Congress, Hannover, Germany, p. 300-306.

Misra AK \& Tyagi S 2007 In vivo embryo production in buffalo: present and perspectives. Italian J. Anim. Sci, 6 (Suppl. 2) 74-91.

Montiel U 2000 Aspectos reproductivos de la búfala. Comportamiento reproductivo en bufalas en un ambiente de bosque muy seco tropical. I Simposium Internacional de Búfalos de Venezuela, Maracaibo, p. 5-20.

Neglia G, Rendina M, Balestrieri A, Grasso FL, Potena A, Russo 1 \& Zicarelli L. 2009 Influence of a swimmingpool on fertility in buffalo species. Ital. I. Anim. Sci. 8 (Suppl. 2) 637-639.

Paul SS \& Lal D 2010 Nutrient requirement of buffaloes, 
Satish Serial Publishing House.

Parmeggiani A \& Di Palo R 1994 Melatoniná e stagionalitạ riproduttiva della bufala. Atti Conv. su "Miglioramento dell'efficienza produttiva e riproduttiva della specie bufalina" Agricolture e Ricerca 153 41-48.

Pelagalli A, d'Angelo D, Mastellone V, Lombardi P, Avallone L, Zicarelli G, Sattar A, \& Zicarelli L 2009 Influence of buffalo dams reproductive status on sexual hormone activity in bulls, Pakistan Journal Zoology, Supplementary Series, No 9, p. 61-63.

Qureshi MS, Samad HA, Habib, Usman RH \& Siddiqui MM 1999a Study on factors leading to seasonality of reproduction in dairy buffaloes. I. Nutritional factors. Asian-Aust, J. Anim. Sci. 12 1019-1024.

Qureshi MS, Habib RH, Samad HA, Lodhi LA \& Usman RH 1999 b Study on factor's leading to seasonality of reproduction in dairy buffaloes. II. Non-nutritional factors. Asian-Aust, I. Anim. Scl. 12 1025-1030.

Qureshi MS, Habib G, Nawab G, Siddiqui MM, Ahmad N \& Samad HA 2000 Milk progesterone profiles in various reproductive states in dairy buffaloes under field conditions. Proc. Natl. Sci. Council Taipei Taiwan 24 70-75.

Razdan MN, Kakar ML \& Galhotra MM 1981 Serum luteinizing hormone levels of non cycling buffaloes (Bubalus bubalis). Indian I. Anim. Sci. 51 286-288.

Roy A, Raizada BC, Pandey MD, Yadav PC \& Sengupta BP 1968 Effect of management on the fertility of buffalo cows bred during summer. Ind. I. Vet. Sci. 38554.

Seren E, Parmeggiani A, Mongiorgi S, Zicarelli L, Montemurro N, Pacelli C, Campanile G, Esposito L, Di Palo R, Borghese A, Barile VL, Terzano GM, Annicchiarico G, \& Allegrini S 1994 Modificazioni endocrine durante il ciclo ovarico nella bufala. Agricoltura e Ricerca 153 17-24.

Shah SNH 1990 Prolonged calving intervals in the Nili Ravi buffalo. PhD Thesis, Utrecht University.

Sheth AR, Wadadekar KB, Moodbidri SB, Janakiraman K \& Paramesh M 1978 Seasonal alteration in the serum prolactin and LH levels in the water buffaloes. Curr. Sci. 47 75-77.

Singh G 1988 Seasonal trend of calving and subsequent service-period in rural buffaloes in Punjab (India). Acta Vet.Scand. 83 80-84.

Singh M, Chavdhary KC \& Takkar OP 1988 Increasing the reproduction performance of buffaloes. Proceedings of the Second World Buffalo Congress, New Delhi, p. 271-282.

Singh B \& Lal K 1992 Effect of season and breed on certain reproductive traits in buffaloes under village condition. Indian I. Anim. Res. 26 15-19.

Vale WG, Ohashi OM, Sousa JS \& Ribeiro HFL 1990 Studies on the reproduction of water buffalo in the Amazon Valley, Brazil. Livestock Reproduction in Latin America. International Atomic Energy Agency, Vienna, p. 201-210.
Vale WG, Ribeiro HFL, Silva AOA, Sousa JS, Ohashi OM \& Souza HEM 1996 Buffalo a non-seasonal breeder in the Amazon Valley, Brazil. Proceedings of the 13th International Congress on Animal Reproduction, Vol. 3, Sydney, p. 19-33.

Vittoria A 1997 Third course on biotechnology of reproduction in buffaloes, Supplement, Bubalus bubalis, 4 15-20.

Zicarelli L 1994 Management in different environmental conditions. Buf, I. Suppl. 2 17-38.

Zicarelli L 1997 Reproductive seasonality in buffalo. Proceedings of the 3 th International Course of Biotechnology in Buffalo Reproduction, Napoli, Suppl. Bubalus bubalis, p. 29-52.

Zicarelli 11999 Nutrition in dairy buffaloes. Perspectives of buffalo husbandry in Brazil and Latin America. Tonhati $\mathrm{H}$, Barnabe VH, Baruselli PS (Eds), Funep, Jabuticabal. p. 157-178.

Zicarelli L 2000 Considerations about the prophylaxis of the uterine and vaginal prolapse in Italian Mediterranean buffalo cows. Bubalus bubalis 3 p. 71-90.

Zicarelli L 2007 Can we consider buffalo a non precocious and hypofertile species? Italian I. Anim. Sci. 6 (Suppl. 2) 143-154.

Zicarelli L, Di Lella T \& de Franciscis G 1977 Osservazioni e rilievi sui parametri riproduttivi e produttivi di bufale in allevamento presso un'azienda della piana del Sele. Acta Med. Vet. 23 183-206.

Zicarelli L, Campanile G, Infascelli F, Esposito L \& Ferrari G 1988 Incidence and fertility of heats with double ovulations in the Mediterranean buffalo cows of Italy. Proceedings of the Second World Buffalo Congress, New Delhi, India, p. 57-62.

Zicarelli L, Campanile G, Esposito L, Di Palo R, Boni R, Spadetta M, Montemurro N, Pacelli C, Borghese A, Barile VL, Terzano GM, Annicchiarico G, Allegrini S, De Benedetti A, Malfatti A, Lucaroni A \& Todini L 1994 Anaestro e induzione dell'estro in bufale acicliche, (Anoestrus and oestrus induction in acyclic buffaloes), Agric, Ric. 153 25-40.

Zicarelli L, Esposito L, Campanile G, Di Palo R \& Armstrong DT 1997 Effect of using vasectomized bulls in A.l. practice on the reproductive efficiency of Italian buffalo cows. Anim. Reprod. Sci. 47 171-180.

Zicarelli L, Di Palo R, Neglia G, Ariota B, Varricchio E \& Campanile G 2007 Estimation of the intercalving period in Italian Mediterranean buffalo. 1tal. J. Anim. Sci. 6 (Suppl. 2) 709-712.

Zoheir KMA, Abdoon AS, Mahrous KF, Amer MA, Zaher MM, LiGuo Y \& El-Nahass EM 2007 Effects of season on the quality and in vitro maturation rate of Egyptian buffalo (Bubalus bubalis) oocytes. I. Cell. Anim. Biol. 129-33. 